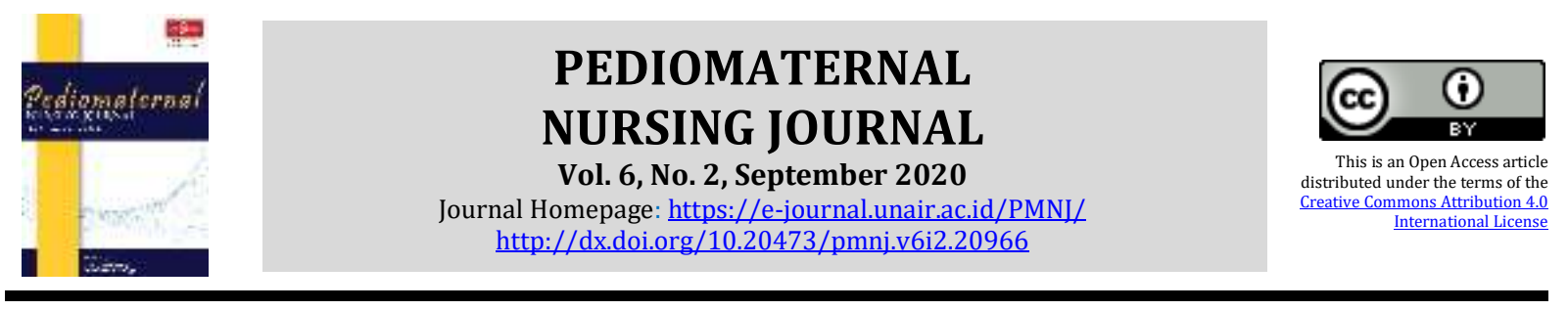

Original Research

\title{
The Correlation Between Personal Reference: Health Workers and Health Facilities with Parenting in Stunting Prevention
}

\author{
Dita Fajrianti, Esti Yunitasari, Retnayu Pradanie
}

Faculty of Nursing, Universitas Airlangga, Surabaya, Indonesia

\author{
ARTICLE HISTORY \\ Received: July 25, 2020 \\ Accepted: August 19, 2020 \\ Published: Augustus 20, \\ 2020

\section{KEYWORDS \\ parenting; stunting; prevention}

\section{CORRESPONDING AUTHOR} \\ Dita Fajrianti \\ dita.fajrianti- \\ 2016@fkp.unair.ac.id \\ Faculty of Nursing, \\ Universitas Airlangga, \\ Surabaya, Indonesia
}

Cite this as:

\begin{abstract}
Introduction: The influence of parenting, the scope and quality of health services, the environment, and food are the leading causes of stunting. This study aims to analyze the correlation between personal reference and health facilities with parenting in stunting prevention in Madura East Java.

Methods: The design of this study was a cross-sectional study. The population in this study were mothers who had children aged 6-24 months in Madura East Java with 149 mothers and obtained a sample of 109 mothers selected using a purposive sampling technique. The independent variable was the personal reference and health facilities. At the same time, the dependent variable was parenting in stunting prevention. The data were collected using a questionnaire. The questionnaire has been a validity and reliability test. This study was analyzed using the Spearman rho test with a significance level $\alpha<0.05$.
\end{abstract}

Results: Personal reference have a correlation in parenting in stunting prevention with significance $(\mathrm{p}=0.017 ; \mathrm{r}=0.228)$ Health care facilities have a correlation in parenting in stunting prevention with significance $(\mathrm{p}=0.020 ; \mathrm{r}=0.222)$

Conclusion: Personal reference and health facilities have a significant role in parenting in stunting prevention. Health workers are expected to be able to provide interventions that are compatible with stunting prevention factors to reduce the incidence of stunting in Indonesia. The more complete health facilities to provide information about pediatric health, the more capable the mother to provide prevention in stunting on children.

Fajrianti, Dita., Yunitasari, E., \& Pradanie, R. (2020). The Correlation Between Personal Reference: Health Workers and Health Facilities with Parenting in Stunting Prevention. Pediomaternal Nurs. J., 6(2), 125-132. Doi: http://dx.doi.org/10.20473/pmnj.v6i2.20966

\section{INTRODUCTION}

Stunting in toddlers required particular attention because it is the impact on stunted physical growth, diminished mental ability, and health status in children (Masrul, 2018). The influence of parenting, the scope and quality of health services, the environment, and food are the main causes of stunting (Kemenkes, 2018). According to Loya and Nuryato (2017), the direct cause of the occurrence of stunting is the intake, the intake given to the child must be according to the child's needs and according to (Yudianti 
and Saeni, 2016) indirect cause of stunting is parenting. Parenting is the family's ability to provide time, attention, and support to children so that children can grow and develop optimally physically, mentally, and socially (Picauly and Toy, 2013). Based on research Aramico et al., (2016), poor parenting has a risk of being stunted 8 times greater than the subjects of good parenting research. Poor parenting patterns are incomplete immunization, ineffective breastfeeding, personal hygiene, and environmental sanitation (Aramico et al., 2016). A personal reference is someone who is considered as an important person so that the person's behavior will be used as a role model such as health workers, religious leaders, tribal leaders, village heads, and etc. (Notoadmojo, 2010). Support from health workers is one of the important supports in improving health, preventing, and curing diseases by providing education and motivation (Kemenkes RI, 2015).

The data on the prevalence of stunting toddlers collected by WHO shows that Indonesia is the third highest country of stunting toddlers in Southeast Asia (Kemenkes, 2018). Based on data from the Republic of Indonesia Ministry of Health (2018) states that there are 160 districts with the highest incidence of stunting, one of which is East Java, with a proportion of $27.5 \%$ incidence. In East Java, there are 11 districts and cities that have the highest prevalence of stunting, namely Bangkalan, Bondowoso, Probolinggo, Nganjuk, Lamongan, Jember, Malang, Kediri, Sampang, Pamekasan, and Sumenep (Kemenkes, 2018). Based on data from the Pamekasan District Health Office in 2019, the priority stunting areas were Batumarmar, Pasean, Panaguan, Sopaah, and Tlanakan. In the Panaguan Public Health Center, there are 737 stunting toddlers.

Problems in exclusive breastfeeding, lack of stimulation of the child's psychosocial development, incorrect feeding practices, poor sanitation practices, inadequate child health care, and inadequate immunization are the causes of stunting (Picauly and Toy, 2013). Mother and baby interaction through breastfeeding will help children to have stable emotions and better social development (Latifah et al., 2010). The practice of feeding children is very important because it will influence the growth of children, besides sanitation practices also play a very important role in the growth of children, if the students are bad and the environment is dirty, it will make it easier for children to get infections that allow children to have diarrhea and be threatened with stunting (MCA Indonesia, 2013). Stunting in children will have an impact on productivity in adulthood. Stunting children also experience difficulties in learning to read, the potential for imperfect growth and development, low motor ability and productivity, and a high risk of suffering from non-communicable diseases (Widanti, 2017).

Handling of stunting by the government is done through specific interventions and sensitive interventions aimed at the first 1000 days of a child's life until he is 6 years old (Kementerian Desa Pembangunan Daerah Tertinggal dan Transmigrasi, 2017). The government has also established presidential regulation no 42 in 2013 on accelerating nutrition improvement. The incidence of stunting can be prevented in 10 ways; namely, pregnant women can increase blood tablets, supplementary feeding to pregnant women, fulfillment of nutrition, delivery with a skilled doctor or midwife, IMD, exclusive breastfeeding, proper MP-ASI (Complementary feeding) delivery, complete immunization, monitor growth and conduct PHBS (Kementerian Desa Pembangunan Daerah Tertinggal dan Transmigrasi, 2017).

Based on the explanation, health workers and health facilities can affect stunting on children. The aimed of this study to analyze the correlation between personal reference and health facilities with parenting in stunting prevention.

\section{METHOD}

\subsection{Design}

Research conducted was a type of descriptive-analytic research with a crosssectional approach.

\subsection{Population, Samples, and Sampling}

The population in this study were mothers who had children aged 6-24 months in Madura East Java with 149 mothers and obtained a sample of 109 mothers selected using a purposive sampling technique. 
Inclusion criteria are mothers who have children aged 6-24 months, mothers who live at home with their children, mothers who can read and write. The exclusion criteria are mothers with children with chronic diseases (congenital heart disease, kidney disease, leukemia, HIV / AIDS, neurological diseases, diabetes mellitus, etc.) and mothers with children with mental disorders.

\subsection{Variables}

The independent variable was personal reference: health workers and health facilities. The dependent variable was parenting in stunting prevention.

\subsection{Instruments}

Personal reference questionnaire includes questions about the role played by health workers in health services that have been tested for validity and reliability consisting of 5 items. Interview guides use a Likert scale with answer choices always, often, sometimes, and never. Positive T data score $\geq$ mean and negative $\mathrm{T}$ data $<$ mean (Azizah, 2019).

The parenting in stunting prevention questionnaire includes questions on the way the mother did in preventing stunting, which had been carried out with a validity and reliability test consisting of 15 questions. Interview guides use a Likert scale with answer choices always, often, sometimes, and never. Scores are given good parenting for $\mathrm{T}$ data $\geq$ mean, and less parenting for $\mathrm{T}$ data $<$ mean. This questionnaire is a questionnaire that is made by the researcher based on theory (Latifah et al., 2010; Picauly and Toy, 2013; Dewi, A. P., Darwin, E., and Edison, 2014; Aji, D. S. K., Kusumawati, E., and Rahardjo, 2016; Susanto, C. K., Wahani, A., and Rompis, 2016; Kemenkes, 2018).

\subsection{Procedure}

Arranging letters from the nursing faculty, political research center, then to the health department and the Panaguan Health Center. After being given permission by the health center, the researcher coordinated with the head of the Panaguan health center (Puskesmas) nutrition department to obtain respondent data in accordance with the researchers' criteria. The health center's coordinator then contacted the midwife in the village to coordinate research that would be conducted in several villages in the Panaguan health center (Puskesmas) working area. The researcher then coordinates with the village midwife to determine the population, then identify the respondent from the total population according to the researcher's needs. Next, the researcher conducts an ethical test for the feasibility of the study. The researcher explained the purpose and steps of the research to the respondent and gave informed consent to the research respondent to be signed, after which the respondent fills in the questionnaire. The data collection procedure was done by filling out the questionnaire at the respondent's house (door to door). Each questionnaire filling totaling 23 questions takes as much as 10 minutes. The respondent that has not been explained about the research, the researcher did not take data from those respondents; after filling out the questionnaire, respondents were given education about stunting prevention and souvenirs from researchers. After the questionnaire has been collected, data analysis would be carried out, which included the process of editing, coding, and analyzing data.

\subsection{Analysis}

This research was conducted with IBM SPSS Statistics 22 with the Spearman rho test with a significance level of $\mathrm{p}<0.05$.

\subsection{Ethical Clearance}

This research has been conducted an ethics test at the Faculty of Nursing Airlangga University and has been declared to pass the ethical review with the number of ethics certificate No. 1940-KEPK on March 12, 2020.

\section{RESULT}

The results of the univariate analysis showed that the majority of respondents were in the early adult category of age 26-35 years as many as 67 mothers (61.5\%) most of the mothers lived with their husbands and children as many as 71 mothers $(65.1 \%)$. The most recent level of education of mothers is only graduated from Elementary School (SD), namely as many as 36 mothers (33.0\%). The data above shows the majority of husband's 
Table 1 Characteristics of respondent demographic data $(\mathrm{n}=109)$

\begin{tabular}{lcc}
\hline Characteristics & $\mathbf{n}$ & $\mathbf{\%}$ \\
\hline Mother's age & & \\
17 - 25 years & 22 & 20.2 \\
26-35 years & 67 & 61.5 \\
36-45 years & 20 & 18.3 \\
Family Form & & \\
Big & 38 & 34.9 \\
Core & 71 & 65.1 \\
Mother's Education & & \\
No education & 21 & 19.3 \\
Uncompleted primary school & 16 & 14.7 \\
Graduated from elementary school & 36 & 33 \\
Graduated Middle School & 19 & 17.4 \\
Graduated high school & 12 & 11 \\
Bachelor & 5 & 4,6 \\
Father's occupation & & \\
Unemployed & 0 & 0 \\
Daily worker & 53 & 48.6 \\
Entrepreneur & 34 & 31.2 \\
Employee & 22 & 20.2 \\
Mother's occupation & & \\
Unemployed & 56 & 51.4 \\
Daily worker & 29 & 26.6 \\
Entrepreneur & 16 & 14.7 \\
Employee & 8.3 \\
Age of the child & & \\
6-8 months & & \\
9-12 months & & 13.8 \\
13-17 months & & 22 \\
18-24 months & & 20.2 \\
Gender of Children & & 44 \\
Fale & & \\
Basic Childhood Immunization Status & 24 & 54.1 \\
Complete & 22 & 45.9 \\
Incomplete & 48 & 68.8 \\
\hline & & 31.2 \\
\hline
\end{tabular}

work as day laborers are 53 people (48.6\%), and the majority of mothers do not work are 56 mothers (51.4\%). In the demographic data of most children, respondents aged 18-24 months were 48 children (44.0\%), and the majority of children were male, namely 59 children (54.1\%). As many as 75 children received complete immunization of 5 types based on the Ministry of Health of the Republic of Indonesia, namely Hepatitis B, BCG, Polio $(1,2,3,4)$, DPT $(1,2,3)$, and measles.

In the variable personal reference, most respondents had references from positive health workers with parenting in stunting prevention good as many as 36 respondents (33\%), while respondents who had references from negative health workers with less parenting in stunting prevention were 31 respondents $(28.4 \%)$. Based on the results of the statistical analysis test shows that there is a significant correlation between personal reference with parenting in stunting prevention $(p=0.017)$. Still, the correlation between the two has a low/weak correlation $(r=0.228)$. Based on the distribution of respondents' answers, health workers often provide information about stunting. Counseling is given when the respondent visits the health center or integrated services post (Posyandu) and when delivering the counseling material, the health worker always delivers the material clearly so that the respondent understands what the health worker has explained. In addition, health workers always provide support to respondents to always bring their children to the integrated services post (posyandu) to monitor their children's health. With support from these health workers, the respondents made positive references to health workers. 
Table 2. The correlation between personal reference and parenting in stunting prevention $(\mathrm{n}=$ 109)

\begin{tabular}{|c|c|c|c|c|c|c|}
\hline \multirow{3}{*}{ Personal reference } & \multicolumn{4}{|c|}{ Parenting In Stunting Prevention } & \multirow{2}{*}{\multicolumn{2}{|c|}{ Total }} \\
\hline & \multicolumn{2}{|c|}{ Less } & \multicolumn{2}{|c|}{ Good } & & \\
\hline & $\mathbf{n}$ & $\%$ & n & $\%$ & n & $\%$ \\
\hline Negative & 31 & 28.4 & 22 & 20.2 & 53 & 48.6 \\
\hline Positive & 20 & 18.3 & 36 & 33 & 56 & 51.4 \\
\hline \multirow[t]{2}{*}{ Total } & 51 & 46.8 & 58 & 53.2 & 109 & 100 \\
\hline & \multicolumn{6}{|c|}{$p=0.017 r=0.228$} \\
\hline
\end{tabular}

Table 3. The correlation between health facilities and parenting in stunting prevention $(n=109)$

\begin{tabular}{|c|c|c|c|c|c|c|}
\hline \multirow{3}{*}{ Health facilities } & \multicolumn{4}{|c|}{ Parenting In Stunting Prevention } & \multirow{2}{*}{\multicolumn{2}{|c|}{ Total }} \\
\hline & \multicolumn{2}{|c|}{ Less } & \multicolumn{2}{|c|}{ Good } & & \\
\hline & $\mathbf{n}$ & $\%$ & $\mathbf{n}$ & $\%$ & n & $\%$ \\
\hline Incomplete & 21 & 19.3 & 12 & 11 & 33 & 30.3 \\
\hline Complete & 30 & 27.5 & 46 & 42.2 & 76 & 69.7 \\
\hline \multirow[t]{2}{*}{ Total } & 51 & 46.8 & 58 & 53.2 & 109 & 100 \\
\hline & \multicolumn{6}{|c|}{$p=0.020 r=0.222$} \\
\hline
\end{tabular}

In the variable health facilities, most of the respondents stated that health facilities are complete and capable of providing preventative care stunting well as many as 46 respondents (42.2\%). Still, respondents who have incomplete health facilities and stunting prevention care is lacking as many as 21 respondents (19.3\%). Statistical analysis showed that there was a significant correlation between health facilities and stunting prevention care $(p=0.020)$, and the correlation between the two was classified as low/weak $(r=0.222)$. Equipped health facility is easy to reach medical facilities, have a means of transportation to health facilities, and has a rate that can be reached by the whole society for treatment and health check. Based on the distribution of respondents, most respondents stated that it could reach the health facilities, access to transportation, and able to reach rates of health facilities.

\section{DISCUSSION}

4.1 The correlation between personal reference: health workers with parenting in stunting prevention

Based on the distribution of data shows that the majority of respondents have positive references to health workers and can take care of stunting prevention well (34.9\%). Based on the distribution of respondents' answers stated that health workers always give encouragement to always bring children to the integrated services post (posyandu) and support to always monitor children's health.

There are no studies that specifically address health workers with stunting prevention, but there are studies that discuss the health of children, namely research conducted by Windari et al., (2017). The study states that there is a significant correlation between health care support and feeding patterns in stunting children. The better the support of health workers, the better the behavior of mothers, so this study is also in line with the study, which states that there is a correlation between health care workers and patterns of parenting in preventing stunting.

Mothers who received home visit assistance had a greater chance of giving exclusive breastfeeding to children compared to mothers who did not get assistance (Yuwono et al., 2016). Research conducted by Dranesia et al., (2019) states that exclusive breastfeeding is one factor that can reduce the number of stunting events. If the child is exclusively breastfed, the risk of stunting will decrease because of the nutritional content in breast milk that can prevent infection and can increase the child's immune system. Good immunity will affect and support the child's optimal growth process. Research conducted by Juwita (2018) stated that the support of health workers was one of the important factors in providing immunizations to children. The support given to mothers in the form of communication, information, and education with this support mothers will be 
motivated to bring their children to carry out immunizations.

The researchers assume that support from health workers is one factor that can help change maternal care for the better. Nursing educational support programs can help improve maternal knowledge and attitudes in feeding patterns to stunted children (Suryawati et al., 2020). Mothers who get more support get education about breastfeeding skills, the benefits of exclusive breastfeeding, and also get support from the family (Liu et al., 2016). The better the support of health workers, the more information will be obtained by the mother so that she can care for the child properly and can prevent stunting.

\subsection{The correlation health facilities with parenting in stunting prevention}

Based on the results of the study showed that there is a significant correlation between health facilities with parenting in stunting prevention. Most respondents who have complete health facilities are able to take care of stunting prevention which as many as 47 respondents (43.1\%).

There are no studies that specifically address the correlation between health facilities and stunting prevention. However, there are research results that discuss health facilities with the practice of maternal, infant and child health services, namely research conducted by Zahtamal et al., (2011) and Adriana et al., (2014) which states that there is a significant the correlation between access to health services with maternal and child health services. The study states that poor health practices are due to difficult access to health facilities, limited transportation, high costs, and poor road structure. This is a limiting factor in the use of health facilities. The more difficult the accessibility of health facilities, the more minimal information and health services obtained by the community will affect health behavior. If maternal health services are not sustainable, it will have an impact on the complete immunization status of children (Sulistiyowati et al., 2017).

Research conducted by (Nainggolan and Tjandrarini, 2016) states that there is a correlation between travel time to a health facility and the completeness of immunization in children because if the time needed to go to the old health facility, the community would reconsider traveling far only for health problems which they say are not a serious illness. Mothers will choose the nearest health facility because it considers many things, such as the inconvenience of carrying children over long distances and long periods of time, as well as other activities that must be completed. The community will use health service facilities if the available access is easily accessible (Nainggolan and Tjandrarini, 2016). Immunization for children is important to protect children from infection, if the child does not get immunized, the risk of a child being infected will be greater because immunization will increase the child's immunity (Nainggolan and Tjandrarini, 2016). Complete health facilities will facilitate the public to obtain information and make it easier for the community always to monitor children's health so that stunting prevention can be done well. Mother's education also influences the utilization of health facilities (Mahwati et al., 2015), respondents' demographic data show that the majority of maternal education in Proppo District is low, only elementary school graduates. The higher the mother's education, the more aware of the child's health and provide good care so that the child will avoid stunting. Researchers assume that the more complete the health facilities, the easier it will be for the public to get information and make it easier for the community always to monitor the health of children so that the care provided by mothers will be better and stunting can be prevented.

\section{CONCLUSION}

Health workers have a significant correlation with parenting in stunting prevention. Support provided by health workers is providing counseling on stunting, supporting mothers to always bring their children to the integrated services post (posyandu) or puskesmas to monitor children's health. Health support will affect the mother's parenting patterns, the better the support, the better the mother's parenting style will be, and stunting can be prevented. 


\section{ACKNOWLEDGEMENT}

I would also like to thank all the respondents who took the time to participate in this research as well as to the Panaguan health center.

\section{CONFLICT OF INTEREST}

The authors declare that there is no conflict of interest.

\section{REFERENCES}

Adriana, N. et al. (2014) 'Akses Pelayanan Kesehatan Berhubungan dengan Pemanfaatan Fasilitas Persalinan yang Memadai di Puskesmas Kawangu , Kabupaten Sumba Timur Access to Health Service related to Use of Antenatal Care Facilities at the Kawangu Health Centre , East Sumba', Public Health and Preventive Medicine Archive, 2, pp. 176-181.

Aji, D. S. K., Kusumawati, E., and Rahardjo, S. (2016) 'Analisis Faktor-Faktor Yang Berpengaruh Terhadap Pola Asuh Ibu Balita di abupaten Banyumas (Studi di Puskesmas Banyumas dan Puskesmas II Kembaran', Kesmas Indonesia, 8(1), pp. 1-15.

Aramico, B., Sudargo, T. and Susilo, J. (2016) 'Hubungan sosial ekonomi, pola asuh, pola makan dengan stunting pada siswa sekolah dasar di kecamatan lut tawar, kabupaten aceh tengah', Jurnal Gizi dan Dietetik Indonesia (Indonesian Journal of Nutrition and Dietetics), 1(3), pp. 121130.

Azizah, R. (2019) Analisis Faktor Pola Pemberian Makan Pada Balita Stunting Berdasarkan Determinan Perilaku WHO. Universitas Airlangga.

Dewi, A. P., Darwin, E., and Edison, E. (2014) 'Hubungan Tingkat Pengetahuan Ibu dengan Pemberian Imunisasi Dasar Lengkap pada Bayi di Kelurahan Parupuk Tabing Wilayah Kerja Puskesmas Lubuk Buaya Kota Padang Tahun 2013', Jurnal Kesehatan Andalas, $3(2)$.

Dranesia, A., Wanda, D. and Hayati, H. (2019) 'Pressure to eat is the most determinant factor of stunting in children under 5 years of age in Kerinci region, Indonesia ६', Enfermería Clínica. Elsevier España, S.L.U., $\quad(\mathrm{xx}) . \quad$ doi: 10.1016/j.enfcli.2019.04.013.

Juwita, R. (2018) 'Faktor-faktor yang mempengaruhi status imunisasi dasar pada bayi di Desa Air Putih Kecamatan Sungai Lala Kabupaten Indragiri Hulu', Al-Tamimi Kesmas: Jurnal Ilmu Kesehatan Masyarakat (Journal of Public Health Sciences), 7(2), pp. 11-21.

Kemenkes (2018) 'Buletin Stunting', Kementerian Kesehatan Republik Indonesia, 301(5), pp. 1163-1178.

Kemenkes RI (2015) Profil Kesehatan Indonesia.

Kementerian Desa Pembangunan Daerah Tertinggal dan Transmigrasi (2017) 'Buku saku desa dalam penanganan stunting', Buku Saku Desa Dalam Penanganan Stunting, p. 42.

Latifah et al. (2010) 'Pengaruh Pemberian ASI dan Stimulasi Psikososial Terhadap Perkembangan Sosial-Emosi Anak Balita Pada Keluarga Ibu Bekerja dan Tidak Bekerja', Jurnal Ilmu Keluarga \& Konsumen, 3(1), pp. 35-45.

Liu, L. et al. (2016) 'The Effect of a Perinatal Breastfeeding Support Program on Breastfeeding Outcomes in Primiparous Mothers', pp. 1-18. doi: $10.1177 / 0193945916670645$.

Loya and Nuryato (2017) 'Pola Asuh Pemberian Makan Pada Balita Stunting Usia 6-12 Bulan Di Kabupaten Sumba Tengah Nusa Tenggara Timur', Journal of Nutrition College, 6(1), pp. 83-95.

Mahwati, Y. et al. (2015) 'Pemanfaatan Pelayanan Kesehatan Ibu di Jawa Barat Maternal Health Care Utilization in West Java', (75).

Masrul, E. S. R. M. (2018) 'Faktor-Faktor yang Berhubungan dengan Kejadian Stunting pada Anak Usia 24-59 Bulan di Wilayah Kerja Puskesmas Andalas Kecamatan Padang Timur Kota Padang Tahun 2018 Eko', Jurnal Kesehatan Andalas, 7(2), pp. 275-284. 
MCA Indonesia (2013) Stunting dan Masa Depan Indonesia, Millenium Challenge Account-Indonesia, 2010.

Nainggolan, O. and Tjandrarini, D. H. (2016) 'Pengaruh Akses ke Fasilitas Kesehatan terhadap Kelengkapan Imunisasi Baduta ( Analisis Riskesdas 2013 )', (August 2018). 10.22435/mpk.v26i1.4900.15-28.

Notoadmojo, S. (2010) Ilmu Perilaku Kesehatan. Jakarta: Rineka Cipta.

Picauly and Toy (2013) 'Analisis Determinan Dan Pengaruh Stunting Terhadap Prestasi Belajar Anak Sekolah Di Kupang Dan Sumba Tmur, NTT', Jurnal Gizi dan Pangan, 8(1), pp. 55-62.

Sulistiyowati, N., Hidayangsih, P. S. and Tjandrarini, D. H. (2017) 'Kesinambungan Pemanfaatan Pelayanan Kesehatan Maternal di Indonesia Kesinambungan Pemanfaatan Pelayanan Kesehatan Maternal di Indonesia', (November). doi: 10.22435/bpk.v45i3.6657.177-186.

Suryawati, L., Harmayetty, H., and Has, E. M. M. A. (2020) 'The Effect of Supportive Educative Nursing Program on Mother's Knowledge and Attitude of Feeding Practice among Stunting Children Aged 6-24 Months', Pediomaternal Nursing Journal, 6(2).

Susanto, C. K., Wahani, A., and Rompis, J. (2016) 'Hubungan Pemberian Imunisasi
BCG dengan Kejadian TB paru Pada Anak di Puskesmas Tuminting Periode Januari 2012-Juni 2012', e-CLinic, 4(1).

Widanti (2017) 'Prevalensi, faktor risiko, dan dampak stunting pada anak usia sekolah', Jurnal Teknologi dan Industri Pangan, 1(1).

Windari, E. N., Dewi, A. K., and Siswanto, S. (2017) 'Pengaruh Dukungan Tenaga Kesehatan Terhadap Pemberian ASI eksklusif Di Wilayah Kerja Puskesmas Sisir Kelurahan Sisir Kota Batu', Journal of Issues in Midwifery, 1(2), pp. 19-24.

Yudianti and Saeni, R. H. (2016) 'Pola Asuh Dengan Kejadian Stunting Pada Balita', Jurnal Kesehatan Manarang, 2(1), pp. 21-25.

Yuwono, S. R., Taufiqurrahman. And Sulendri, N. K. S. (2016) 'Pendampingan Ibu Hamil Trimester III Meningkatkan Praktek Pemberian Asi dan Status Gizi Balita 0-4 Bulan (III Trimester Pregnant Women Mentoring Improve Breastfeeding Practice and Nutritional Status Of 0-4 Months Children ) Slamet Riyadi Yuwono *, Taufiq', Jurnal Ners, 11(2), pp. 311314.

Zahtamal, Z., Restuastuti, T., and Chandra, F. (2011) 'Analisis Faktor Determinan Permasalahan Pelayanan Kesehatan Ibu dan Anak', Kesmas: National Public Health Journal, 6(1), pp. 9-16. 